\section{Molecular characterisation of a supernumerary ring chromosome in a patient with VATER association}

EDITOR-Supernumerary marker chromosomes are rare with an incidence of 0.3-1.5/1000 newborns. Most carriers have a normal phenotype but in $15 \%$ of non-satellited marker cases mental retardation and minor anomalies have been reported. ${ }^{1}$ The origin of several supernumerary ring marker chromosomes has been identified by fluorescence in situ hybridisation (FISH). ${ }^{2}$ The VATER association is characterised by non-random occurrence of Vertebral anomalies, Anal atresia, Tracheo-oesophageal fistula with Esophageal atresia, Radial limb dysplasia, and Renal defects. ${ }^{3}$ The acronym VACTERL is used in cases with additional Cardiac and Limb malformations. ${ }^{4}$ VACTERL with hydrocephalus is thought to be an autosomal recessive disorder distinct from the VATER association. ${ }^{5}$ Other defects that occur less frequently have been also described. ${ }^{6}$ A defect in blastogenesis was suggested as a possible aetiology of this malformation spectrum. Martìnez-Frìas et $a l^{7}$ proposed that combinations of anomalies of blastogenetic origin, such as VATER/VACTERL, should be considered and called "polytopic field defects" instead of the generic term "association".

The knowledge that maternal intake of some teratogens, such as oestroprogestins ${ }^{8}$ or methimazole, ${ }^{9}$ may be associated with VATER/VACTERL in the newborn, probably affecting blastogenesis, and familial occurrence of VASTER/VACTERL ${ }^{1011}$ suggest heterogeneity in the pathogenesis of the association, although it appears that the underlying causative event takes place at a very early stage of embryonic development.

Only one chromosome abnormality has been described in VATER association, a patient with an interstitial $6 \mathrm{q}$ deletion, ${ }^{12}$ while an additional case of VATER with $9 \mathrm{qh}+$ has been reported. ${ }^{13}$

We report here an additional patient with malformations characteristic of VATER association and mosaicism for a small supernumerary ring chromosome derived from the pericentromeric region of chromosome 12 .

The proband was the term product of an uneventful pregnancy, requiring elective caesarean section because of uterine inertia. Birth weight was $3520 \mathrm{~g}$, length $51 \mathrm{~cm}$, and OCF $33 \mathrm{~cm}$. At birth, an anorectal malformation with urethral fistula was detected and surgical correction was performed on the second day of life. Skeletal $x$ ray showed multiple dorsal and lumbar hemivertebrae, sacral agenesis, and multiple left fused ribs. He underwent neurosurgical correction for the presence of a medullary lipoma, thickened terminal filum, and hydromelia. No radial ray defects were observed. Ultrasound examination showed absence of the left kidney. There were no cardiac or tracheal anomalies. Psychomotor development was normal and he now attends primary school. The parents are phenotypically normal.

Analysis of the patient's karyotype showed the presence, in both lymphocytes and fibroblasts, of a supernumerary small ring chromosome in $63 \%$ of metaphases. The marker chromosome did not show any specific QFQ or GTG banding pattern and it was DA/DAPI negative. The small supernumerary ring chromosome was a de novo anomaly since both parents had a normal karyotype.

The origin of the ring chromosome was ascertained by performing FISH with an alphoid DNA probe specific for several chromosomes and hybridisation was successfully accomplished using the alphoid DNA specific for chromosome 12 . The hybridisation signal was present on the centromere of both chromosomes 12 and covered almost the whole ring (fig 1A, B).

In order to establish the presence of euchromatic material, we used some overlapping YAC clones (CEPH MegaYAC library) specific for the 12q12 (cen-956_a_5, 958_e_2-tel) and 12p11-p12.1 (cen-832_f_14, 952_a_6, 753_f_12, 922_d_9, 927_g_11,806_c_2, 792_b_12-tel) regions (fig 2). YAC 922_d_9 contains the SOX 5 gene. ${ }^{14}$ All YAC clones were selected on the basis of the available consensus $\operatorname{map}^{15}$ and provided by the YAC Screening Center (DIBIT-HSR and IGBE-CNR Milano Italy, http:// www.spr.it/iger/home.html). FISH analysis with YAC clones specific for the $12 \mathrm{q} 12$ region showed that the hybridisation signal of YAC clone 956_a_5 was present on the ring with the same intensity as the ones present on both chromosomes 12 . This resulted in chimerism since the hybridisation signal was also present on $4 \mathrm{q} 12,9 \mathrm{p} 23,6 \mathrm{q} 13$, and $11 \mathrm{p} 14$. The YAC portion on chromosome 12 is located immediately next to the centromere; the distal YAC 958_e_2 gave no signal on the ring chromosome. The 956_a_5 and 958_e_2 YAC clones overlap for the presence of a STS constructed on the end of the corresponding YAC clone (958e2-R), while the distal 943f6-R STS is present only in the YAC 958_e_2. ${ }^{15}$ These results allowed us to localise the breakpoint on the long arm of chromosome 12, probably in the region between the YAC clones 956_a_5 and 958_e_2 containing the two STS constructed on the end of the corresponding YAC clones (958e2-R and 943f6-R).

On the other hand, several YAC clones (832_f_14, 952_a_6, 753_f_12 and 922_d_9) specific for the 12p11p12.1 region gave an intense hybridisation signal on the ring chromosome, indicating that the marker was mainly made up of a portion of chromosome 12 short arm. Additionally, two YAC clones, 927_g_11 and 806_c_2, have been identified probably containing the breakpoint, since the hybridisation signals on the marker chromosome were less intense than the signals on both chromosomes 12 (fig 1C, D, E, F). The distal YAC 792_b_12, which gave no signal on the ring chromosome, overlaps with both YACs 927_g_11 and 806_c_2 for the presence of the AFM267yc9 marker (Whitehead Institute/MIT site: http:// www.genome.wi.mit.edu/). Since YAC 927_g_11, which contains the breakpoint, and the proximal YAC 922_d_9 are positive for the marker AFMb351zh5 (http:// www.genome.wi.mit.edu/), the breakpoint on the short arm of chromosome 12 could be located between markers AFM267yc9 and AFMb351zh5 (fig 2). On the basis of these molecular data, the patient is trisomic for the $12 \mathrm{p} 12.1-\mathrm{q} 12$ region included between the markers AFM267YC9 and STS on the end of the 943_f_6 YAC clone (943f6-R) and containing the centromere. Thus the ring chromosome is composed of a portion of the q12 region contained in the positive YAC 956_a_5 and mainly $\mathrm{p}$ arm sequences. Finally, the proband's karyotype was interpreted as follows: 46, XY/47, XY $+\mathrm{r}(12)(\mathrm{p} 12.1 \mathrm{q} 12)$. 

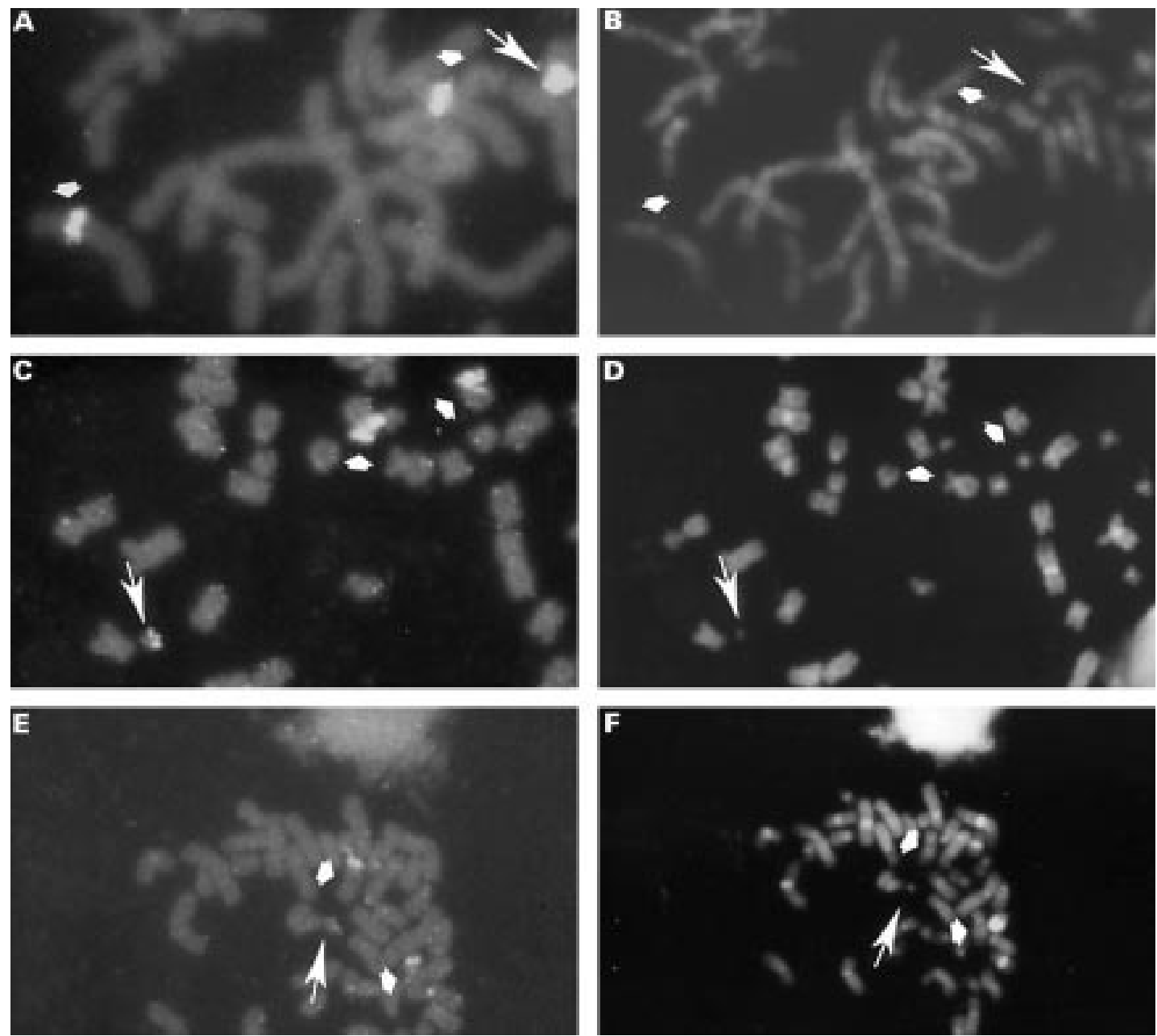

Figure 1 FISH experiments using $(A)$ an alphoid DNA probe specific for chromosome 12; (C) 927_g_11, and (E) 806_c_2 YAC clones. $(B, D, F)$ The same partial metaphases stained with DAPI. The large arrows show the ring chromosome and the small arrows the normal chromosome 12 pair.

Since the SOX5 gene maps to $12 \mathrm{p} 12.1,{ }^{14}{ }^{16}$ immediately next to one of the breakpoints, two BAC clones, bK906D14 and bK943I5 (RPC-11 Human BAC library), containing the 5' genomic sequence of the h-L-SOX5 gene were also used in FISH experiments. The two BAC clones, like YAC 922_d_9, gave a hybridisation signal of the same intensity on both chromosome 12 and on the ring chromosome, indicating that the gene probably does not span one of the breakpoints.

To the best of our knowledge, the present case is the second report of a patient with VATER association and a karyotype anomaly. In order to obtain a karyotype/ phenotype correlation, we reviewed all published cases with a supernumerary ring chromosome 12 . To date, an extra small ring chromosome 12 mosaicism was described in a patient with delayed development and vescicoureteric reflux and in a fetus. ${ }^{2}$ In the latter case, no clinical data were reported because fetal necropsy was not performed after pregnancy termination. In both cases the small ring chromosomes were only defined as deriving from the pericentromeric region of chromosome 12 and were not molecularly characterised in order to verify the presence of euchromatic material from the short and/or the long arm of chromosome 12 .

Although the ring chromosome is a different condition from the duplication of the same chromosomal region, nevertheless we reviewed all reported cases with similar duplications. We found only patients with bigger duplications, some of which partially overlapped the region defined by us. Most reported cases were partially or totally trisomic for the chromosome 12 short arm and their clinical phenotypes were included in the spectrum of $12 \mathrm{p}$ trisomy. ${ }^{17}$ We selected only the patients who had a "pure" partial or total $12 \mathrm{p}$ trisomy, that is, derived from a direct or inverted tandem duplication or from a malsegregation of a parental balanced reciprocal translocation of $12 \mathrm{p}$ onto the short arm of an acrocentric chromosome. ${ }^{18-27}$ Among these, three were mosaic cases and the full spectrum of $12 p$ trisomy syndrome was present. ${ }^{192125}$ Only two patients had a duplication also including the q12 region. ${ }^{18}{ }^{26}$ To the best of our knowledge, no other cases with a duplication of the long arm of chromosome 12 overlapping the critical interval defined by us have been reported.

The $12 \mathrm{p}$ trisomy syndrome has a well recognised spectrum of anomalies; congenital malformations of the internal organs are rare in "pure" $12 p$ duplications. The frequency of malformations, however, seems to increase with the extent of the imbalance. The patient described here does not show the $12 \mathrm{p}$ syndrome phenotype. Our clinical and molecular findings could support the hypothesis previously reported that the critical duplicated segment causing $12 \mathrm{p}$ trisomy syndrome is located distally to our $12 \mathrm{p}$ breakpoint, in $\mathrm{p} 13.1-\mathrm{p} 13.3 .{ }^{21}$ Our proband has a complex phenotype with multiple dorsal and lumbar hemivertebrae, sacral agenesis, anorectal malformation, and unilateral kidney agenesis. According to the criteria of Quan and Smith, ${ }^{3}$ we conclude that our patient has VATER association. 


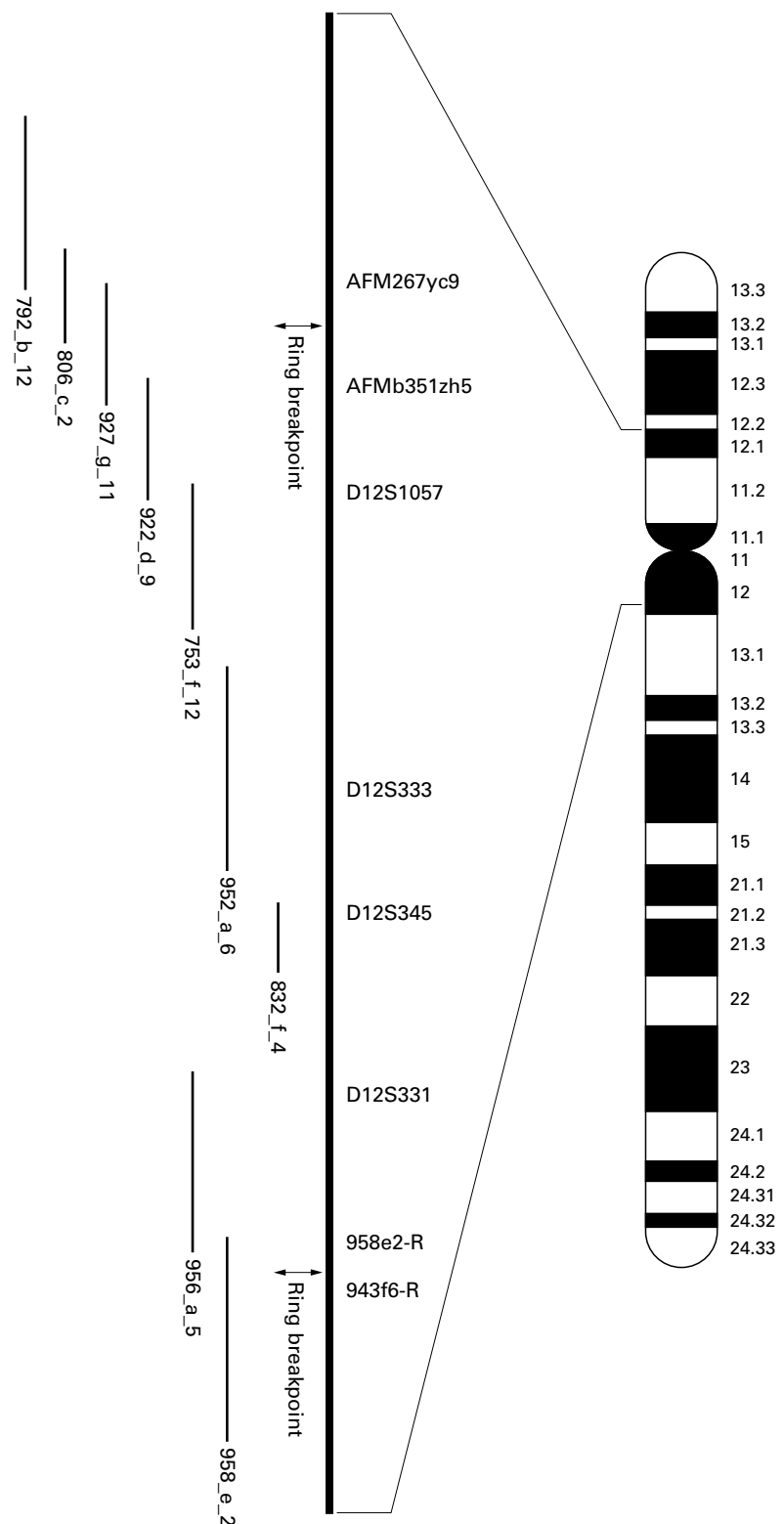

Figure 2 Schematic representation of all the YAC clones specific for the 12p12.1-q12 region used in FISH experiments. The physical data are summarised from Mostert et al, ${ }^{13}$ Krauter et al, ${ }^{14}$ and from the Whitehead Institute/MIT site (http://www.genome.wi.mit.edu/).

One of the reported patients with the larger duplication including the $12 \mathrm{q} 12$ region had bilateral hydronephrosis with a rudimentary left kidney, ${ }^{26}$ similar to the present case.
Among the reported cases with complete duplication of $12 \mathrm{p}$, one patient had anal atresia, ${ }^{18}$ another one had cerebral ventricular dilatation, ${ }^{19}$ and two other patients had cardiac anomalies, ${ }^{18}{ }^{27}$ while the remaining cases did not show any internal organ malformations (table 1).

Although ring chromosomes have been well characterised, the pathogenetic mechanism remains to be understood. We could postulate three hypotheses. The first one is that the patient's phenotype could be the result of the presence of the supernumerary ring chromosome. On reviewing all the above mentioned published cases, we could not define a precise karyotype/phenotype correlation. However, on the basis of the two previously described patients, one with the bigger duplication including the $12 \mathrm{q} 12$ region and a rudimentary left kidney ${ }^{26}$ and the other with a supernumerary ring 12 chromosome and vescicoureteric reflux, ${ }^{2}$ we cannot rule out the possibility that the presence of the trisomic q12 segment might mainly determine the patient's phenotype.

In the $12 \mathrm{p} 12.1-\mathrm{q} 12$ region, several genes and as yet uncharacterised ESTs have been identified (Human GeneMap '99) whose triple dosage could determine a development defect causing a pathological phenotype. Among the genes, possible candidates are $S O X 5^{16}$ and the human homologue (BICD1) of the Drosophila Bicaudal gene (Bic$d{ }^{28}$ because of their role during embryonic development. Particularly, gain of function mutations of Bic-d in Drosophila disrupt the establishment of anterior and posterior polarity in the early embryo. ${ }^{29}$ However, we do not know if the genes contained in this supernumerary chromosome are normally expressed.

The second hypothesis is that the breakpoints of the rearrangement could interrupt the coding sequence of a gene with a negative dominant effect by the eventually translated truncated protein. Since the SOX 5 gene maps in $12 \mathrm{p} 12.1,{ }^{14}{ }^{16}$ immediately next to one of the breakpoints, we performed FISH experiments to verify this hypothesis. Our results indicated that the gene was unlikely to span the breakpoint. However, these data do not exclude the involvement of other genes. Additionally, a dominant negative or a deleterious effect could be determined by the presence of a chimeric gene caused by the fusion of two coding sequences spanning the breakpoints.

The third hypothesis is that the cytogenetic anomaly and the pathological phenotype could be randomly associated, although the supernumerary ring chromosome was observed in a large percentage, $63 \%$, of mitoses. In this respect, mosaicism for a small de novo supernumerary 12 marker chromosome was reported in a normal child. ${ }^{30}$ Thus, the features of VATER association presented by our patient could be the result of a germinal or somatic mutation of a gene not localised in the critical interval defined by

Table 1 Clinical features of reviewed cases with supernumerary ring 12 chromosomes and larger partially overlapping duplications compared with present case. The proband's phenotype and similar features observed in the other cases are in bold

\begin{tabular}{|c|c|c|}
\hline Reported cases & Partial trisomy & Phenotype \\
\hline Present case & 12p12.1-q12 (ring chromosome) & $\begin{array}{l}\text { Dorsal and lumbar hemivertebrae, sacral agenesis, anorectal } \\
\text { malformation, unilateral kidney agenesis, rib fusion }\end{array}$ \\
\hline Callen et al, case $5^{2}$ & Chr 12 pericentromeric region (ring chromosome) & Delayed development, vescicoureteric reflux \\
\hline Callen et al, case $4^{2}$ & Chr 12 pericentromeric region (ring chromosome) & Undetermined \\
\hline Rethoré $e t a l^{26}$ & 12 pter-q12 & $\begin{array}{l}\text { Bilateral hydronephrosis, rudimentary left kidney } \\
12 \text { p syndrome }\end{array}$ \\
\hline Kondo et $a l^{25}$ & & $12 \mathrm{p}$ syndrome \\
\hline Stengel-Rutkowsky et al, case $1^{18}$ & 12 pter-q12 & $\begin{array}{l}\text { Congenital heart disease, incomplete intestinal rotation, Meckel } \\
\text { diverticulum, } 12 \mathrm{p} \text { syndrome }\end{array}$ \\
\hline Stengel-Rutkowsky et al, case $2^{18}$ & 12 pter-p11 & Anal atresia, hypospadias, $12 \mathrm{p}$ syndrome \\
\hline Guerrini et $a l^{19}$ & 12 pter-p11 & Cerebral malformation, $12 \mathrm{p}$ syndrome \\
\hline Biederman et al ${ }^{7}$ & 12pter-p11 & Congenital heart disease, $12 \mathrm{p}$ syndrome \\
\hline Rauch et $a l_{,}^{21}$ Rivera et al ${ }^{4}$ & 12 pter-p11 & $12 \mathrm{p}$ syndrome \\
\hline Rauch et al, case $1^{21}$ & 12 pter-p11.21 & $12 \mathrm{p}$ syndrome \\
\hline Pfeiffer $e t a l^{0}$ & $12 \mathrm{p} 13.3-\mathrm{p} 11.2$ & $12 \mathrm{p}$ syndrome \\
\hline Rauch et $a l^{21}$ Allen et $a l,{ }^{22}$ Back et al ${ }^{3}$ & 12 pter-12.1 & $12 \mathrm{p}$ syndrome \\
\hline
\end{tabular}


us. To the best of our knowledge, one subject with VACTERL has been found to have a somatic point mutation in mitochondrial DNA from kidney tissue. ${ }^{31}$

We thank Dr Benoit de Chrombrugge and Dr Veronique Lefebre (Department of Molecular Genetics, M D Anderson Cancer Center, Houston, Texas) for the SOX 5 BAC clones and Dr M Mancini (YAC Screening Centre, San Raffaele Biomedical Science Park, Milano Italy) for the YAC clones. R Cinti is supported by a Fellowship awarded by the Italian Ministry of Health.

ROBERTA CINTI* MANUELA PRIOLO* MARGHERITA LERONE* GIORGIO GIMELLI* MARCO SERI* MARGHERITA SILENGO $†$ ROBERTO RAVAZZOLO **Laboratory of Molecular Genetics, Istituto G Gaslini, Largo G Gaslini 5, 16148 Genova, Italy †Department of Paediatric and Adolescent Sciences, University of Turin, 10121 Turin, Italy $\ddagger$ Department of Oncology, Biology and Genetics, University of Genoa, 16132 Genoa, Italy

Correspondence to: Dr Cinti, milonga@tin.it

1 Warburton D. De novo chromosome rearrangements and extra marker chromosomes identified at prenatal diagnosis: clinical significance and distribution of breakpoints. Am f Hum Genet 1991;49:995-1013.

2 Callen DF, Eyre HJ, Ringenbergs ML, Freemantle CJ, Woodroffe P, Haan EA. Chromosomal origin of small ring marker chromosomes in man: characterization by molecular genetics. Am F Hum Genet 1991;48:769-82.

3 Quan L, Smith DW. The VATER association: Vertebral defects, Anal atresia, T-E fistula with esophageal atresia, Radial and Renal dysplasia: a spectrum of associated defects. $\mathcal{F}$ Pediatr 1973;82:104-7.

4 Baumann W, Greinacher I, Emmerich P, Spranger J. VATER oder VACTERL Syndrom. Klin Pediatr 1976;188:328-37.

5 Evans JA, Stranc LC, Kaplan P, Hunter AGW. VACTERL with hydrocephalus: further delineation of the syndrome(s). Am $\mathcal{f}$ Med Genet 1989;34:177-82.

6 Botto LD, Khoury MJ, Mastroiacovo P, Castilla EE, Moore CA, Skjaerven R, Mutchinick OM, Borman B, Cocchi G, Czeizel AE, Goujard J, Irgens LM, Lancaster PAL, Martínez-Frías ML, Merlob P, Ruusinen A, Stoll C, Sumiyoshi Y. The spectrum of congenital anomalies of the VATER association: an international study. Am f Med Genet 1997;71:8-15.

7 Martínez-Frías ML, Frías JL, Opitz JM. Errors of morphogenesis and developmental field theory. Am $\mathcal{F}$ Med Genet 1998;76:291-6.

8 Nora JJ, Nora AH. Birth defects and oral contraceptives. Lancet 1973;i:9412.

9 Ramirez A, Espinosa de los Monteros A, Parra A, De Leon B. Esophageal atresia and tracheoesophageal fistula in two infants born to hyperthyroid women receiving methimazole (Tapazol) during pregnancy. Am 7 Med Genet 1992;44:200-2.

10 Auchterloine IA, White MP. Recurrence of the VATER association within a sibship. Clin Genet 1982;21:122-4.

11 Nezarati MM, McLeod DR. VACTERL manifestations in two generations of a family. Am $\mathcal{F}$ Med Genet 1999;82:40-2.
12 McNeal RM Skoglund RR, Francke U. Congenital anomalies including the VATER association in a patient with a del(6)q deletion. F Pediatr 1977;91: 957-60.

13 Aynaci FM, Celep F, Karakšzel A, Baki A, Yildiran A. A case of VATER association associated with 9qh+. Genet Counsel 1996;7:321-2.

14 Mostert MC, Verkerk AJMH, van de Pol M, Heighway J, Marynen P, Rosenberg C, van Kessel AG, van Echten J, de Jong B, Oosterhuis JW, Looijenga HJ. Identification of the critical region of $12 p$ overrepresentation in testicular germ cell tumors of adolescents and adults. Oncogene 1998;16:2617-27.

15 Krauter K, Montgomery K, Yoon SJ, LeBlanc-Stracesky J, Renault B, Marondel I, Herdman V, Cupelli L, Banks A, Lieman J, Menninger J, Bray-Ward P, Nadkarni P, Weissenbah J, Le Paslier D, Rigault P, Chumakov I, Cohen D, Miller P, Ward D, Kucherlapati R. A second-generation YAC contig map of human chromosome 12. Nature 1995;377(suppl):321-33.

16 Wunderle VM, Critcher R, Ashworth A, Goodfellow PN. Cloning and characterization of $S O X 5$, a new member of the human SOX gene family. Genomics 1996;36:354-8.

17 Uchida IA, Lin CC. Identification of partial 12 trisomy by quinacrine fluorescence. $\mathcal{F}$ Pediatr 1973;82:269-72.

18 Stengel-Rutkowski S, Albert A, Murken JD, Zahn-Messow K, Rodewald A, Zankl M, Saule H, Stene J. New chromosomal dysmorphic syndromes. Trisomy 12p. Eur F Pediatr 1981;136:249-62.

19 Guerrini R, Bureau M, Mattei MG, Battaglia A, Galland MC, Roger J. Trisomy $12 \mathrm{p}$ syndrome: a chromosomal disorder associated with generalized 3-Hz spike and wave discarges. Epilepsia 1990;31:557-66.

20 Pfeiffer RA, Legat G, Trautmann U. Acrocallosal syndrome in a child with de novo inverted tandem duplication of 12p11.2-p13.3. Ann Genet 1992;35: 41-6.

21 Rauch A, Trautmann U, Pfeiffer RA. Clinical and molecular cytogenetic observations in three cases of "trisomy $12 \mathrm{p}$ syndrome". Am f Med Genet 1996;63:243-9.

22 Allen TL, Brothman AR, Carey JC, Chance PF. Cytogenetic and molecular analysis of trisomy 12p. Am ₹ Med Genet 1996;63:250-6.

23 Back E, Kratzer W, Zeitler S, Schempp W. De novo duplication of 12 pter $\rightarrow$ p12.1: clinical and cytogenetic diagnosis confirmed by chromosome painting. Clin Genet 1997;51:205-10

24 Rivera H, Vasquez AI, Perea FJ. Centromere-telomere $(12 ; 8 \mathrm{p})$ fusion, telomeric 12q translocation, and i(12p) trisomy. Clin Genet 1999;55:122-6.

25 Kondo I, Hamaguchi H, Haneda T. Trisomy 12p syndrome. De novo occurrence of mosaic trisomy $12 \mathrm{p}$ in a mentally retarded boy. Hum Genet 1979; 46:135-40.

26 Rethoré MO, Kaplan JC, Junien C, Cruveiller J, Dutrillaux B, Aurias A, Carpentier S, Lafourcade J, Lejeune J. Augumentation de l'activité de la LDH-B chez un garcon trisomique $12 \mathrm{p}$ par mal ségrégation d'une translocation maternelle t $(12 ; 14)$ (q12;p11). Ann Genet 1975;18:81-7.

27 Biederman B, Bowen P, Robertson C, Schiff D. Partial trisomy 12p due to t(12;21)pat translocation. Hum Genet 1977;36:35-41.

28 Baens M, Marinen P. A human homologue (BICD1) of the Drosophila Bicaudal-D gene. Genomics 1997;45:601-6.

29 Wharton RP, Struhl G. Structure of the Drosophila Bicaudal-D protein and its role in localizing the posterior determinant nanos. Cell 1989;59:881-92.

30 Crolla JA, Dennis NR, Jacobs PA. A non-isotopic in situ hybridisation study of chromosomal origin of 15 supernumerary marker chromosomes in man. f Med Genet 1992;29:699-703.

31 Damian MS, Seibel P, Schachenmayr W, Reichmann H, Dorndorf W. VACTERL with the mitochondrial np 3243 point mutation. Am f Med Genet 1996;62:398-403. 